\title{
Enantiomeric oxidation of organic sulfides by the filamentous fungi Botrytis cinerea, Eutypa lata and Trichoderma viride
}

\author{
Cristina Pinedo-Rivilla, Josefina Aleu, Isidro G. Collado* \\ Departamento de Química Orgánica, Facultad de Ciencias, Universidad de Cádiz, \\ República Saharaui s/n, Apdo. 40, 11510 Puerto Real, Cádiz, Spain
}

Received 21 December 2006; received in revised form 4 July 2007; accepted 6 July 2007

Available online 12 July 2007

\begin{abstract}
The biotransformations of a series of substituted sulfides were carried out with the filamentous fungi Botrytis cinerea, Eutypa lata and Trichoderma viride. Several products underwent microbial oxidation of sulfide to sulfoxide with medium to high enantiomeric purity. With regard to sulfoxide enantioselectivity, the $(R)$-enantiomer was favoured in biotransformations by $T$. viride and $E$. lata while the $(S)$-enantiomer was favoured in those by $B$. cinerea. A minor amount of sulfone product was also obtained.
\end{abstract}

(C) 2007 Elsevier B.V. All rights reserved.

Keywords: Biotransformation; Chiral sulfoxide; Botrytis cinerea; Eutypa lata; Trichoderma viride

\section{Introduction}

Enantiomerically pure sulfoxides are useful building blocks for the synthesis of pharmaceuticals and biologically active compounds [1]. As natural products, they occur in a variety of functionalized amino acids possessing various biological activities. These range from being flavour and aroma precursors [2] and regulators of cholesterol catabolism [3] to having antibiotic properties [4].

Several methods are available for the synthesis of these sulfoxides; the most useful is Andersen's method [5] and the selective oxidation of sulfides with chiral binaphtol [6] and Schiff-base vanadium (IV) compounds [7]. In recent years, biocatalytic methods that make use of microorganisms and isolated enzymes have emerged as an advantageous alternative for this purpose [8]. This makes it possible to exploit the high regio- and stereoselectivity inherent in the reactivity of most enzymes by using oxidative enzymes themselves as reagents for sulfoxidation. Isolated enzymes may be used simply as chiral catalysts in many redox or hydrolytic applications [9]. In the case of oxidative reactions that are catalyzed by oxygenase enzymes and which occur directly at unactivated carbon or sulfur

\footnotetext{
* Corresponding author. Tel.: +34 956016368 ; fax: +34 956016193 .

E-mail address: isidro.gonzalez@uca.es (I.G. Collado).
}

atoms, whole microbial cells are often used. These cells systems circumvent the problems associated with the isolation of the complex oxygenase enzymes and has been used extensively in the study of enzymic sulfoxidation [10]. Thus, even though the enantioselectivities are less spectacular than those achieved with isolated enzymes, for use on a preparative scale, this way of producing chiral sulfoxides is more convenient. To date, biological oxidation of sulfides to sulfoxides by means of whole cells has employed mainly fungi and bacteria and, to a lesser extent, yeasts [11-13].

Among the fungi used in the oxidation of sulfides, Helminthosporium species and Mortierella isabellina have been amply studied [14-18]. Sulfoxides of the amino acids methionine and ethionine with the $(S)$-configuration can be obtained through biotransformation of the appropriately protected amino acids with Beauveria species [19,20]. In addition, fungi of the Rhizopus [21] and Aspergillus [22] species have also been found to stereospecifically oxidize prochiral sulfides to the corresponding sulfoxides.

In this paper, we report on our results concerning the oxidative potential of the filamentous fungi Botrytis cinerea, Trichoderma viride and Eutypa lata whole cells in the transformation of sulfides into sulfoxides. In many cases sulfoxides are obtained in good yields and with high enantiomeric purity, which suggests a possible application especially for $T$. viride in the preparativescale production of such chiral sulfoxides. 


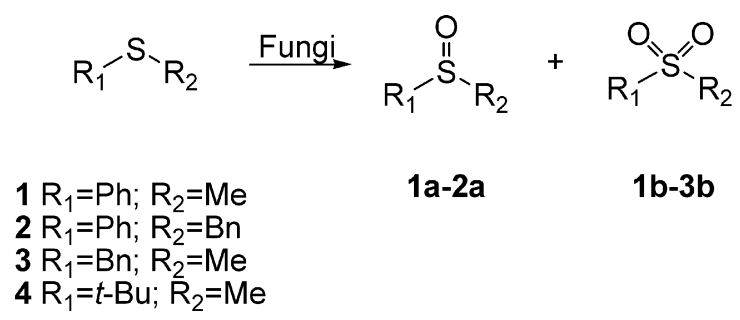

Scheme 1. Bioxidation of sulfides 1-4 by the filamentous fungi Botrytis cinerea, Eutypa lata and Trichoderma viride.

\section{Results and discussion}

Four sulfides (1-4) were subjected to the action of whole cells of three filamentous fungi, namely B. cinerea, E. lata and T. viride, in order to verify the biocatalytic potential of these fungi for the bioxidation of sulfides (Scheme 1). The results of the biotransformations are presented in the Tables 1 (static cultures) and 2 (shaken cultures) in terms of isolated yields, enantiomeric excesses and predominant configurations of sulfoxide products, together with isolated yields of sulfones. The reason shaken cultures were included was to increase the broth oxidation in order to facilitate the sulfoxidation reaction.
The assignments of product structure relied on NMR information, ${ }^{1} \mathrm{H}$ and ${ }^{13} \mathrm{C}$ spectral data being diagnostic of the oxidation state at sulfur. These, together with supporting mass spectral data, are presented in Section 4. The enantiomeric excess of sulfoxide products were determined by means of HPLC analyses on a chiral column (Chiralcel OD, Daicel, Japan): $254 \mathrm{~nm}, 0.5 \mathrm{~mL} / \mathrm{min}$, hexane:isopropanol (9:1), and the absolute configurations were determined by comparing the specific rotations with data from the literature [23].

The best results for the oxidation of thioanisole (1) were obtained with $T$. viride, which gave the $(R)$-methyl phenyl sulfoxide (1a) with $70 \%$ ee on a static culture, and with B. cinerea, which gave the $(S)$-sulfoxide with $50 \%$ ee on a shaken culture. Most of the biotransformations with sulfide 1 occurred with low conversion, with sulfone $\mathbf{1 b}$ being formed in most cases. The best yield obtained for $\mathbf{1 b}$ was $46 \%$ by $B$. cinerea.

As can be seen in Table 1, the yields for methyl phenyl sulfoxide (1a) decreased with time in most cases. This suggests that the major enantiomer of the sulfoxide is transformed into sulfone.

Biotransformation of benzyl phenyl sulfide (2) by B. cinerea afforded the (S)-benzyl phenyl sulfoxide (2a), but with low conversion and enantiomeric excess. The $(R)$-benzyl phenyl sul-

Table 1

Biotransformation of sulfides on static cultures

\begin{tabular}{|c|c|c|c|c|c|c|c|c|c|c|c|c|c|}
\hline \multirow[t]{3}{*}{ Substrate } & \multirow{3}{*}{$\begin{array}{l}\text { Time } \\
\text { (days) }\end{array}$} & \multicolumn{4}{|c|}{ B. cinerea } & \multicolumn{4}{|c|}{ E. lata } & \multicolumn{4}{|c|}{ T. viride } \\
\hline & & \multicolumn{2}{|c|}{ Sulfoxide } & \multicolumn{2}{|l|}{ Sulfone } & \multicolumn{2}{|c|}{ Sulfoxide } & \multicolumn{2}{|l|}{ Sulfone } & \multicolumn{2}{|c|}{ Sulfoxide } & \multicolumn{2}{|l|}{ Sulfone } \\
\hline & & $\begin{array}{l}\text { Yield } \\
(\%)\end{array}$ & $e e(\%)$ & Configuration & $\begin{array}{l}\text { Yield } \\
(\%)\end{array}$ & $\begin{array}{l}\text { Yield } \\
(\%)\end{array}$ & $e e(\%)$ & Configuration & $\begin{array}{l}\text { Yield } \\
(\%)\end{array}$ & $\begin{array}{l}\text { Yield } \\
(\%)\end{array}$ & $e e(\%)$ & Configuration & $\begin{array}{l}\text { Yield } \\
(\%)\end{array}$ \\
\hline \multirow[t]{4}{*}{1} & 2 & 58 & 41 & $S$ & 46 & $\mathrm{np}$ & - & & $\mathrm{np}$ & 12 & 45 & $\mathrm{R}$ & 6 \\
\hline & 5 & 14 & 15 & S & 41 & np & - & & np & 10 & 70 & $\mathrm{R}$ & 35 \\
\hline & 8 & $\mathrm{np}$ & - & & $\mathrm{np}$ & 2 & 1 & $\mathrm{R}$ & 0 & $\mathrm{np}$ & - & & $\mathrm{np}$ \\
\hline & 15 & np & - & & $\mathrm{np}$ & 2 & 23 & $\mathrm{R}$ & 2 & np & - & & np \\
\hline \multirow[t]{4}{*}{2} & 5 & 6 & 30 & S & 0 & $\mathrm{np}$ & - & & $\mathrm{np}$ & 25 & 76 & $\mathrm{R}$ & 0 \\
\hline & 8 & $\mathrm{np}$ & - & & $\mathrm{np}$ & 49 & 6 & $\mathrm{R}$ & 25 & np & - & & np \\
\hline & 10 & 0 & - & & 16 & $\mathrm{np}$ & - & & $\mathrm{np}$ & 46 & 82 & $\mathrm{R}$ & 0 \\
\hline & 15 & $\mathrm{np}$ & - & & $\mathrm{np}$ & 16 & 11 & $\mathrm{R}$ & 7 & 37 & $88^{\mathrm{a}}$ & $\mathrm{R}$ & 16 \\
\hline \multirow[t]{4}{*}{3} & 2 & 0 & - & & 6 & $\mathrm{np}$ & - & & $\mathrm{np}$ & 0 & - & & 1 \\
\hline & 5 & 0 & - & & 25 & $\mathrm{np}$ & - & & $\mathrm{np}$ & 0 & - & & 19 \\
\hline & 8 & $\mathrm{np}$ & - & & $\mathrm{np}$ & 0 & - & & 1 & $\mathrm{np}$ & - & & $\mathrm{np}$ \\
\hline & 15 & $\mathrm{np}$ & - & & $\mathrm{np}$ & 0 & - & & 4 & $\mathrm{np}$ & - & & $\mathrm{np}$ \\
\hline
\end{tabular}

$\mathrm{np}=$ not performed.

a $>95 \%$ ee after crystallization.

Table 2

Biotransformation of sulfides on shaken cultures

\begin{tabular}{|c|c|c|c|c|c|c|c|c|c|}
\hline \multirow[t]{3}{*}{ Substrate } & \multirow[t]{3}{*}{ Time (days) } & \multicolumn{4}{|l|}{ B. cinerea } & \multicolumn{4}{|l|}{ T. viride } \\
\hline & & \multicolumn{2}{|l|}{ Sulfoxide } & \multicolumn{2}{|l|}{ Sulfone } & \multicolumn{2}{|l|}{ Sulfoxide } & \multicolumn{2}{|l|}{ Sulfone } \\
\hline & & Yield (\%) & $e e(\%)$ & Configuration & Yield (\%) & Yield (\%) & $e e(\%)$ & Configuration & Yield (\%) \\
\hline \multirow[t]{2}{*}{1} & 2 & 32 & 50 & $\mathrm{~S}$ & 2 & 36 & 45 & $\mathrm{R}$ & 5 \\
\hline & 5 & 26 & 49 & $\mathrm{~S}$ & 3 & 20 & 30 & $\mathrm{R}$ & 21 \\
\hline \multirow[t]{2}{*}{2} & 5 & $\mathrm{np}$ & - & & $\mathrm{np}$ & 75 & 94 & $\mathrm{R}$ & 4 \\
\hline & 10 & $\mathrm{np}$ & - & & np & 60 & $>95^{\mathrm{a}}$ & $\mathrm{R}$ & 15 \\
\hline
\end{tabular}

$\mathrm{np}=$ not performed.

a $>99 \%$ ee after crystallization. 
foxide (2a) was obtained with both $T$. viride and E. lata, whereby the oxidation in a shaken culture by the former giving the best enantiomeric excess in good yield ( $>95 \% e e, 60 \%$ ). In this case, the sulfoxide could be crystallized from ethyl acetate/hexane to give an enantiomeric excess $>99 \%$.

The optical purity of this sulfoxide is exceptionally high, and presumably this compound fits especially well into the enzyme system where oxidation occurs. This result indicates a potential application for $T$. viride in the preparative-scale production of this chiral sulfoxide.

The benzyl phenyl sulfone (2b) was obtained by all the fungi, with E. lata affording the best yield. It is remarkable that both the yield and the enantiomeric excess of sulfoxide 2a on a static culture with $T$. viride increased steadily until the 10th day of fermentation, a fact which indicates that the major enantiomer of the sulfoxide was not transformed into the sulfone $\mathbf{2 b}$. In fact, when $\mathbf{2 b}$ was produced on day 15 of the fermentation, the yield of the sulfoxide decreased.

Biotransformation of benzyl phenyl sulfide (2) by $B$. cinerea also afforded the compound $p$-hydroxybenzyl phenyl sulfide (8) in $10 \%$ yield. This result indicates the oxidative potential of this fungus.

The results obtained for benzyl methyl sulfide (3) are summarized in Table 1. As can be seen from the table, in no case was the corresponding sulfoxide found. This sulfide was transformed directly into sulfone $\mathbf{3 b}$ by all the fungi, albeit in low yields. The best result was obtained with $B$. cinerea.

With respect to the $t$-butyl methyl sulfide (4), no biotransformation products were found, which suggests that this compound, the only non-aromatic product tested, was utilized by the fungi as a carbon and sulfur source for their own metabolism, probably because of its structural simplicity.

From the data presented in the tables it is clear that the fungus E. lata is not a satisfactory biocatalytic agent for the bioxidation of prochiral sulfides. This may be due to the low level of growth of this fungus in liquid medium.

\section{Conclusions}

In summary, the studies described above have demonstrated the biocatalytic potential of the filamentous fungi $B$. cinerea, E. lata and T. viride for the bioxidation of prochiral sulfides. Several products gave microbial oxidation of sulfide to sulfoxide in medium to high enantiomeric purity. The enantioselectivity for sulfoxides favoured the $(R)$-enantiomer in the case of $T$. viride and $E$. lata with a high enantiomeric excess when the former was used. In contrast, in bioxidations with $B$. cinerea, the $(S)$ enantiomer was favoured. A minor amount of sulfone product was also obtained.

\section{Experimental}

\subsection{General experimental procedures}

Optical rotations were determined with a Perkin-Elmer 241 polarimeter. IR spectra were recorded on a Mattson Genesis spectrophotometer, series FTIR. ${ }^{1} \mathrm{H}$ and ${ }^{13} \mathrm{C}$ NMR measure- ments were obtained on Varian Gemini 300 and Varian Unity 400 NMR spectrometers with $\mathrm{SiMe}_{4}$ as the internal reference. Mass spectra were recorded on a GC-MS Thermoquest spectrometer (model: Voyager), and a VG Autospec-Q spectrometer. HPLC was performed with a Hitachi/Merck L-6270 apparatus equipped with a UV-vis detector (L 6200) and a differential refractometer detector (RI-71). TLC was performed on Merck Kiesegel 60 $\mathrm{F}_{254}, 0.2 \mathrm{~mm}$ thick. Silica gel (Merck) was used for column chromatography. Purification by means of HPLC was accomplished with a silica gel column (Hibar 60, $7 \mathrm{~m}, 1 \mathrm{~cm}$ wide, $25 \mathrm{~cm}$ long). Chemicals were products of Fluka or Aldrich. All solvents used were freshly distilled. Enantiomeric excesses were determined by means of HPLC analyses on a chiral column (Chiralcel OD, Daicel, Japan): $254 \mathrm{~nm}, 0.5 \mathrm{~mL} / \mathrm{min}$, hexane:isopropanol (9:1) $(R)-\mathbf{1 a} t_{\mathrm{R}}=22.3 \mathrm{~min},(S)-\mathbf{1 a} t_{\mathrm{R}}=25 \mathrm{~min},(R)-\mathbf{2} \mathbf{a} t_{\mathrm{R}}=25 \mathrm{~min},(S)$ 2a $t_{\mathrm{R}}=29 \mathrm{~min}$.

\subsection{Microorganism cultures}

The culture of $B$. cinerea employed in this work, $B$. cinerea (UCA 992), was obtained from grapes from the Domecq vineyard, Jerez de la Frontera, Cádiz, Spain. This culture of $B$. cinerea is deposited in the Universidad de Cadiz, Facultad de Ciencias, Mycological Herbarium Collection (UCA). The $E$. lata and $T$. viride cultures used in this research were obtained from the "Centro Español de Cultivos Tipo" (CECT), Facultad de Biología, Universidad de Valencia, Spain, where cultures of these strains are deposited.

\subsection{General culture conditions}

Fungi were grown at $25^{\circ} \mathrm{C}$ on a Czapeck-Dox medium (B. cinerea UCA 992) or on a PDB medium (E. lata and T. viride) ( $150 \mathrm{~mL}$ per bottle and $200 \mathrm{~mL}$ per flask). The shaken cultures were incubated on an orbital shaker at $140 \mathrm{rpm}$. The substrates were dissolved in ethanol and then distributed over Roux bottles or flasks ( $150 \mathrm{ppm}$ per flask) and the fermentation continued for a further period, after which the mycelium was filtered and then washed with brine and ethyl acetate. The broth was extracted three times with ethyl acetate and the extract was dried over anhydrous sodium sulfate. The solvent was then evaporated and the residue was chromatographed first on a silica gel column and then with HPLC with an increasing gradient of ethyl acetate to petroleum ether.

\subsection{Biotransformation of thioanisole (1)}

\subsubsection{Biotransformation by B. cinerea}

(a) Static culture. Thioanisole (1) was dissolved in ethanol and then distributed over 12 Roux bottles after 2 days' growth. The fermentation was allowed to continue for two more days in six of the bottles and five more days in the other six. Chromatography of the extract fermented for 2 days gave thioanisole (1) (2 mg), methyl phenyl sulfone (1b) $(50 \mathrm{mg})$ and $(S)$-methyl phenyl sulfoxide $(\mathbf{1 a})\left([\alpha]_{D}^{20}:-15.7^{\circ}\left(c 0.1, \mathrm{CHCl}_{3}\right)\right)(22 \mathrm{mg})$. Chromatography of the extract fermented for 5 days gave thioanisole (1) (1 mg), methyl phenyl sulfone (1b) (75 mg) and 
$(S)$-methyl phenyl sulfoxide (1a) $(85 \mathrm{mg})\left([\alpha]_{D}^{20}:-2.3^{\circ}(c 0.9\right.$, $\left.\mathrm{CHCl}_{3}\right)$; lit [23]: $[\alpha]_{D}^{20}:-130.1^{\circ}(90 \%$ ee $)(c$ 1.7, acetone) $)$. (b) Shaken culture. Thioanisole (1) was dissolved in ethanol and then distributed over 10 flasks $(500 \mathrm{~mL})$ in an orbital shaker after 2 days' growth. The fermentation was allowed to continue for two more days in five of the flasks and five more days in the other five. Chromatography of the extract fermented for 2 days gave thioanisole (1) (2 mg), methyl phenyl sulfone (1b) (3 mg) and $(S)$-methyl phenyl sulfoxide (1a) $(54 \mathrm{mg})\left([\alpha]_{D}^{20}:-78.4^{\circ}(c 1.7\right.$, $\left.\mathrm{CHCl}_{3}\right)$ ). Chromatography of the extract fermented for 5 days gave thioanisole (1) (1 mg), methyl phenyl sulfone (1b) $(6.7 \mathrm{mg})$ and $(S)$-methyl phenyl sulfoxide (1a) $(43.1 \mathrm{mg})\left([\alpha]_{D}^{20}:-72.7^{\circ}\right.$ (c 2.1, $\left.\mathrm{CHCl}_{3}\right)$ ).

\subsubsection{Biotransformation by E. lata}

Thioanisole (1) was dissolved in ethanol and then distributed over 12 Roux bottles after 7 days' growth. The fermentation was allowed to continue on static culture for eight more days in six of the bottles and for 15 more days in the other six. Chromatography of the extract fermented for 8 days gave thioanisole (1) $(5.6 \mathrm{mg})$, tyrosol [24] (5) (2 mg), (R)-methyl phenyl sulfoxide (1a) $\left([\alpha]_{D}^{20}\right.$ : $\left.+0.3^{\circ}\left(c 0.2, \mathrm{CHCl}_{3}\right)\right)(3 \mathrm{mg})$ and $p$-hydroxybenzoic acid [25] (6) $(1.5 \mathrm{mg})$. Chromatography of the extract fermented for 15 days gave tyrosol [24] (5) (2 mg), methyl phenyl sulfone (1b) (3 mg), (R)-methyl phenyl sulfoxide (1a) $\left([\alpha]_{D}^{20}:+19.3^{\circ}(c 0.2\right.$, $\left.\mathrm{CHCl}_{3}\right)$ ) (3 mg) and $p$-hydroxybenzoic acid [25] (6) (2.7 mg).

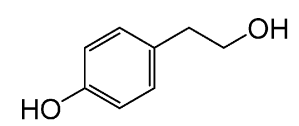

5

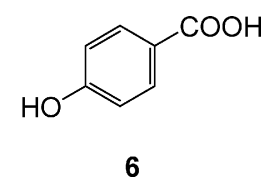

\subsubsection{Biotransformation by T. viride}

(a) Static culture. Thioanisole (1) was dissolved in ethanol and then distributed over 18 Roux bottles after 2 days' growth. The fermentation was allowed to continue for two more days in six of the bottles and for five more days in the other 12. Chromatography of the extract fermented for 2 days gave thioanisole (1) (7.2 mg), 6-pentyl- $\alpha$-pyrone [26] (7) (50 mg), methyl phenyl sulfone (1b) $(8.1 \mathrm{mg})$ and $(R)$-methyl phenyl sulfoxide (1a) $\left([\alpha]_{D}^{20}:+48.9^{\circ}\left(c 1, \mathrm{CHCl}_{3}\right)\right)(16 \mathrm{mg})$. Chromatography of the extract fermented for 5 days gave thioanisole $(\mathbf{1})(6 \mathrm{mg})$, 6pentyl- $\alpha$-pyrone [26] (7) (10 mg), methyl phenyl sulfone (1b) $(100 \mathrm{mg})$ and $(R)$-methyl phenyl sulfoxide (1a) $\left([\alpha]_{D}^{20}:+69^{\circ}\right.$ (c 1.6, $\left.\mathrm{CHCl}_{3}\right)(30 \mathrm{mg})$. (b) Shaken culture. Thioanisole (1) was dissolved in ethanol and then distributed over 10 flasks $(500 \mathrm{~mL})$ in an orbital shaker on a PDB medium after 2 days' growth. The fermentation was allowed to continue for two more days in five of the flasks and for five more days in the other five. Chromatography of the extract fermented for 2 days gave thioanisole (1) (5 mg), 6-pentyl- $\alpha$-pyrone [26] (7) (27 mg), methyl phenyl sulfone (1b) (38 mg) and (R)-methyl phenyl sulfoxide (1a) $\left([\alpha]_{D}^{20}:+58^{\circ}\left(c\right.\right.$ 2.9, $\left.\left.\mathrm{CHCl}_{3}\right)\right)(58.4 \mathrm{mg})$. Chromatography of the extract fermented for 5 days gave 6-pentyl- $\alpha$-pyrone [26] (7) (40 mg), methyl phenyl sulfone (1b) (53 mg) and $(R)$-methyl phenyl sulfoxide $(\mathbf{1 a})\left([\alpha]_{D}^{20}:+36.2^{\circ}\left(c 1.5, \mathrm{CHCl}_{3}\right)(34.2 \mathrm{mg})\right.$.

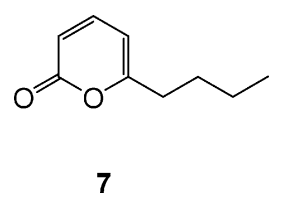

4.4.3.1. Methyl phenyl sulfoxide (1a). Obtained as yellow oil. IR $v_{\max }$ (film): $3446,1444,1090,1036,749,692 \mathrm{~cm}^{-1} ;{ }^{1} \mathrm{HNMR}$ $\left(400 \mathrm{MHz}, \mathrm{CDCl}_{3}\right): \delta 2.71(3 \mathrm{H}, \mathrm{s}), 7.51(3 \mathrm{H}, \mathrm{m}), 7.63(2 \mathrm{H}$, bd); ${ }^{13} \mathrm{C}-\mathrm{RMN}\left(100 \mathrm{MHz}, \mathrm{CDCl}_{3}\right): \delta 43.8,123.4,129.2,130.9$, 145.5; MS $m / z$ (relative intensity): $140\left(\mathrm{M}^{+}, 46\right), 125\left(\mathrm{M}^{+}-15\right.$, 56), 97 (88), 77 (70), 51 (100).

4.4.3.2. Methyl phenyl sulfone (1b). Obtained as a white solid; mp 68-71 ${ }^{\circ} \mathrm{C}$; IR $v_{\max }$ (film): 3023, 1448, 1299, 1150, 1084, $750 \mathrm{~cm}^{-1} ;{ }^{1} \mathrm{H} \mathrm{NMR}\left(400 \mathrm{MHz}, \mathrm{CDCl}_{3}\right): \delta 3.05(3 \mathrm{H}, \mathrm{s}), 7.57$ $(2 \mathrm{H}, \mathrm{t}), 7.65(1 \mathrm{H}, \mathrm{t}), 7.94(2 \mathrm{H}, \mathrm{d}) ;{ }^{13} \mathrm{C}-\mathrm{RMN}\left(100 \mathrm{MHz}, \mathrm{CDCl}_{3}\right)$ : $\delta 44.5,127.7,129.8,134.0,140.5$; MS $\mathrm{m} / z$ (relative intensity): $156\left(\mathrm{M}^{+}, 65\right), 141\left(\mathrm{M}^{+}-15,63\right), 94$ (86), 77 (100), 51 (79).

\subsection{Biotransformation of benzyl phenyl sulfide (2)}

\subsubsection{Biotransformation by B. cinerea}

Benzyl phenyl sulfide (2) was dissolved in ethanol and then distributed over 18 Roux bottles after 2 days' growth. The fermentation was allowed to continue on static culture for five more days in 12 of the bottles and for 10 more days in the other six. Chromatography of the extract fermented for 5 days gave benzyl phenyl sulfide (2) (57.3 mg) and ( $S$ )-benzyl phenyl sulfoxide (2a) $(9 \mathrm{mg})\left([\alpha]_{D}^{20}:-25.4^{\circ}\left(c 0.7, \mathrm{CHCl}_{3}\right)\right)$; Ref. [23]: $[\alpha]_{D}^{20}:-169.8^{\circ}$ (79\% ee) (c 1.0, acetone)). Chromatography of the extract fermented for 10 days gave benzyl phenyl sulfide (2) (17.7 mg), benzyl phenyl sulfone (2b) (21.5 mg) and p-hydroxybenzyl phenyl sulfide (8) (13 mg).

\subsubsection{Biotransformation by E. lata}

Benzyl phenyl sulfide (2) was dissolved in ethanol and then distributed over 18 Roux bottles after 7 days' growth. The fermentation was allowed to continue on static culture for eight more days in 12 of the bottles and for 15 more days in the other six. Chromatography of the extract fermented for 8 days gave benzyl phenyl sulfide (2) (180.2 mg), benzyl phenyl sulfone (2b) $(6.5 \mathrm{mg})$ and $(R)$-benzyl phenyl sulfoxide $(\mathbf{2 a})\left([\alpha]_{D}^{20}:+2.2^{\circ}(c\right.$ $\left.2, \mathrm{CHCl}_{3}\right)$ ) (121 mg). Chromatography of the extract fermented for 15 days gave benzyl phenyl sulfide (2) (70.7 mg), benzyl phenyl sulfone (2b) (10.9 mg) and $(R)$-benzyl phenyl sulfoxide (2a) $\left([\alpha]_{D}^{20}:+5.4^{\circ}\left(c 1.1, \mathrm{CHCl}_{3}\right)\right)(22.3 \mathrm{mg})$.

\subsubsection{Biotransformation by $T$. viride}

(a) Static culture. Benzyl phenyl sulfide (2) was dissolved in ethanol and then distributed over 24 Roux bottles after 2 days' growth. The fermentation was allowed to continue for 5, 10 and 15 more days in three groups. Chromatography of the extract of the first group ( 5 days, 12 bottles) gave benzyl phenyl sulfide (2) (25 mg), 6-pentyl- $\alpha$-pyrone [26] (7) (18 mg) and ( $R$ )-benzyl phenyl sulfoxide $(\mathbf{2 a})\left([\alpha]_{D}^{20}:+74.7^{\circ}\left(c 1.5, \mathrm{CHCl}_{3}\right)\right)(65 \mathrm{mg})$. Chromatography of the extract of the second group (10 days, 
six bottles) gave benzyl phenyl sulfide (2) (21.1 mg), 6-pentyl$\alpha$-pyrone [26] (7) (95 mg) and ( $R$ )-benzyl phenyl sulfoxide (2a) $\left([\alpha]_{D}^{20}:+75.6^{\circ}\left(c 1, \mathrm{CHCl}_{3}\right)\right)(57.1 \mathrm{mg})$. Chromatography of the extract of the third group (15 days, six bottles) gave benzyl phenyl sulfide (2) (10 mg), 6-pentyl- $\alpha$-pyrone [26] (7) (190 mg), benzyl phenyl sulfone (2b) $(23 \mathrm{mg})$, and $(R)$-benzyl phenyl sulfoxide $(\mathbf{2 a})\left([\alpha]_{D}^{20}:+79^{\circ}\left(c\right.\right.$ 0.5, $\left.\left.\mathrm{CHCl}_{3}\right)\right)(50 \mathrm{mg})$. Crystallization from ethyl acetate/hexane of this sulfoxide gave a sample with $\left.[\alpha]_{D}^{20}:+96.2^{\circ}\left(c 1.1, \mathrm{CHCl}_{3}\right)\right)$. (b) Shaken culture. Benzyl phenyl sulfide (2) was dissolved in ethanol and then distributed over 12 flasks $(500 \mathrm{~mL})$ in an orbital shaker on a PDB medium after 2 days' growth. The fermentation was allowed to continue for five more days in six of the flasks and for 10 more days in the other six. Chromatography of the extract fermented for 5 days gave benzyl phenyl sulfide (2) (31.5 mg), 6-pentyl- $\alpha$ pyrone [26] (7) (52.4 mg), benzyl phenyl sulfone (2b) (7 mg) and $(R)$-benzyl phenyl sulfoxide $(\mathbf{2 a})\left([\alpha]_{D}^{20}:+95.1^{\circ}\left(c 1, \mathrm{CHCl}_{3}\right)\right)$ $(121 \mathrm{mg})$. Chromatography of the extract fermented for 10 days gave benzyl phenyl sulfide (2) (11.3 mg), 6-pentyl- $\alpha$-pyrone [26] (7) $(53.2 \mathrm{mg})$, benzyl phenyl sulfone (2b) $(28.5 \mathrm{mg})$ and $(R)$ benzyl phenyl sulfoxide $(\mathbf{2 a})\left([\alpha]_{D}^{20}:+107.7^{\circ}\left(c 2.5, \mathrm{CHCl}_{3}\right)\right)$ $(109.3 \mathrm{mg})$. Crystallization from ethyl acetate/hexane of this sulfoxide gave a sample with $\left.[\alpha]_{D}^{20}:+109.7^{\circ}\left(c 2, \mathrm{CHCl}_{3}\right)\right)$.

4.5.3.1. Benzyl phenyl sulfoxide (2a). Obtained as white solid; $\mathrm{mp} 117-120^{\circ} \mathrm{C}$; IR $v_{\max }$ (film): 3063, 2963, 1442, 1084, $1031,746 \mathrm{~cm}^{-1} ;{ }^{1} \mathrm{H}$ NMR $\left(400 \mathrm{MHz}, \mathrm{CDCl}_{3}\right): \delta 3.98(1 \mathrm{H}, \mathrm{d}$, $J=12.6 \mathrm{~Hz}), 4.08(1 \mathrm{H}, \mathrm{d}, J=12.6 \mathrm{~Hz}), 6.97(2 \mathrm{H}, \mathrm{d}), 7.21-7.27$ $(3 \mathrm{H}, \mathrm{m}), 7.35-7.45(5 \mathrm{H}, \mathrm{m}) ;{ }^{13} \mathrm{C}-\mathrm{RMN}\left(100 \mathrm{MHz}, \mathrm{CDCl}_{3}\right): \delta$ 63.4, 124.3, 128.1, 128.3, 128.7, 128.8, 130.2, 131.0, 142.7; MS $m / z$ (relative intensity): $216\left(\mathrm{M}^{+}, 33\right), 125$ (48), 97 (60), 91 (85), 77 (90), 51 (100).

4.5.3.2. Benzyl phenyl sulfone ( $2 \boldsymbol{b}$ ). Obtained as a white solid; mp $131-133^{\circ} \mathrm{C}$; IR $v_{\max }$ (film): 3062, 2944, 1446, 1308, 1151, $758 \mathrm{~cm}^{-1} ;{ }^{1} \mathrm{H}$ NMR $\left(400 \mathrm{MHz}, \mathrm{CDCl}_{3}\right): \delta 4.31(2 \mathrm{H}, \mathrm{s}), 7.07$ $(2 \mathrm{H}, \mathrm{d}, J=7.5 \mathrm{~Hz}), 7.21-7.33(3 \mathrm{H}, \mathrm{m}), 7.44(2 \mathrm{H}, \mathrm{t}, J=7.5 \mathrm{~Hz})$, 7.56-7.64 (3H, m); ${ }^{13} \mathrm{C}-\mathrm{RMN}\left(100 \mathrm{MHz}, \mathrm{CDCl}_{3}\right): \delta 62.8,128.1$, 128.5, 128.6, 128.7, 128.8, 130.8, 133.7, 137.9; MS m/z (relative intensity): $232\left(\mathrm{M}^{+}, 42\right), 181$ (25), 167 (58), 90 (100), 77 (70), $51(55)$.

4.5.3.3. $p$-Hydroxybenzyl phenyl sulfide (8). Obtained as white solid; mp $167-169^{\circ} \mathrm{C}$; IR $v_{\max }$ (film): $3392,2927,1447,1305$, $1151,1127,748 \mathrm{~cm}^{-1} ;{ }^{1} \mathrm{H}$ NMR $\left(400 \mathrm{MHz}, \mathrm{CDCl}_{3}\right): \delta 4.22$ $(2 \mathrm{H}, \mathrm{s}), 6.70(2 \mathrm{H}, \mathrm{d}), 6.93(2 \mathrm{H}, \mathrm{d}), 7.45(2 \mathrm{H}, \mathrm{t}), 7.62(3 \mathrm{H}$, $\mathrm{m}) ;{ }^{13} \mathrm{C}-\mathrm{RMN}\left(100 \mathrm{MHz}, \mathrm{CDCl}_{3}\right): \delta 62.2,115.6,128.6,128.9$, 132.2, 133.6, 137.9, 151.8, 156.2; MS $m / z$ (relative intensity): $217\left(\mathrm{M}^{+}+1,2\right), 125$ (13), 109 (25), 107 (100), 97 (43), 77 (58), 51 (28).

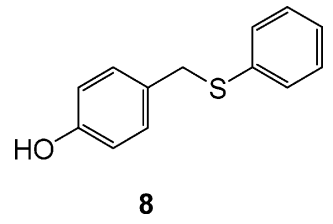

\subsection{Biotransformation of benzyl methyl sulfide (3)}

\subsubsection{Biotransformation by B. cinerea}

Benzyl methyl sulfide (3) was dissolved in ethanol and then distributed over 18 Roux bottles after 2 days' growth. The fermentation was allowed to continue on static culture for two more days in six of the bottles and for five more days in the other 12 . Chromatography of the extract fermented for 2 days gave benzyl methyl sulfide (3) $(2.6 \mathrm{mg})$ and benzyl methyl sulfone (3b) $(10 \mathrm{mg})$. Chromatography of the extract fermented for 5 days gave benzyl methyl sulfide (3) $(5 \mathrm{mg})$ and benzyl methyl sulfone (3b) (55 mg).

\subsubsection{Biotransformation by E. lata}

Benzyl methyl sulfide (3) was dissolved in ethanol and then distributed over 12 Roux bottles after 7 days' growth. The fermentation was allowed to continue on static culture for eight more days in six of the bottles and for 15 more days in the other six. Chromatography of the extract fermented for 8 days gave benzyl methyl sulfide (3) $(6.6 \mathrm{mg})$ and benzyl methyl sulfone (3b) $(1.6 \mathrm{mg})$. Chromatography of the extract fermented for 15 days gave tyrosol [24] (5) (2 mg), $p$-hydroxybenzoic acid [25] (6) $(4.5 \mathrm{mg})$ and benzyl methyl sulfone (3b) $(6 \mathrm{mg})$.

\subsubsection{Biotransformation by T. viride}

Benzyl methyl sulfide (3) was dissolved in ethanol and then distributed over 18 Roux bottles after 2 days' growth. The fermentation was allowed to continue on static culture for two more days in six of the bottles and for five more days in the other 12. Chromatography of the extract fermented for 2 days gave benzyl methyl sulfide (3) (1.9 mg), 6-pentyl- $\alpha$-pyrone [26] (7) $(1.8 \mathrm{mg})$ and benzyl methyl sulfone $(\mathbf{3 b})(1 \mathrm{mg})$. Chromatography of the extract fermented for 5 days gave benzyl methyl sulfide (3) (6.6 mg), 6-pentyl- $\alpha$-pyrone [26] (7) (140 mg) and benzyl methyl sulfone (3b) (14.8 mg).

4.6.3.1. Benzyl methyl sulfone ( $3 \boldsymbol{b})$. Obtained as a white solid; mp $113-115^{\circ} \mathrm{C}$; IR $v_{\max }$ (film): 3014, 1458, 1306, 1120, $788 \mathrm{~cm}^{-1} ;{ }^{1} \mathrm{H}$ NMR $\left(400 \mathrm{MHz}, \mathrm{CDCl}_{3}\right): \delta 2.74(3 \mathrm{H}, \mathrm{s}), 4.24$ $(2 \mathrm{H}, \mathrm{s}), 7.41(5 \mathrm{H}, \mathrm{s}) ;{ }^{13} \mathrm{C}-\mathrm{RMN}\left(100 \mathrm{MHz}, \mathrm{CDCl}_{3}\right): \delta 38.9$, 61.3, 128.2, 129.1, 130.5; MS $\mathrm{m} / \mathrm{z}$ (relative intensity): $170\left(\mathrm{M}^{+}\right.$, 45), $155\left(\mathrm{M}^{+}-15,4\right), 90$ (100), 63 (99).

\subsection{Biotransformation of t-butyl methyl sulfide (4)}

\subsubsection{Biotransformation by B. cinerea}

$t$-Butyl methyl sulfide (4) was dissolved in ethanol and then distributed over 12 Roux bottles after 2 days' growth. The fermentation was allowed to continue on static culture for five more days. Chromatography of the extract gave compounds characteristic of $B$. cinerea.

\subsubsection{Biotransformation by E. lata}

$t$-Butyl methyl sulfide (4) was dissolved in ethanol and then distributed over 12 Roux bottles after 7 days' growth. The fermentation was allowed to continue on static culture for eight 
more days. Chromatography of the extract gave tyrosol [24] (5) $(2 \mathrm{mg})$ and $p$-hydroxybenzoic acid [25] (6) (5 mg).

\subsubsection{Biotransformation by $T$. viride}

$t$-Butyl methyl sulfide (4) was dissolved in ethanol and then distributed over 12 Roux bottles after 2 days' growth. The fermentation was allowed to continue on static culture for five more days. Chromatography of the extract gave 6-pentyl- $\alpha$-pyrone [26] (7) (102 mg) and tyrosol [24] (5) (2 mg).

\section{References}

[1] L.C. Ricci, J.V. Comasseto, L.H. Andrade, Enzyme Microb. Technol. 36 (2005) 937.

[2] R. Kubec, M. Svobodova, J. Velisek, J. Agric. Food Chem. 48 (2000) 1132.

[3] W. Komatsu, Y. Miura, K. Yagasaki, Lipids 33 (1998) 499.

[4] K.H. Kyung, D.C. Han, H.P. Fleming, J. Food Sci. 62 (1997) 406.

[5] P. Page, Organosulfur Chemistry, vol. 2, Academic Press, San Diego, USA, 1998, pp. 41-61.

[6] M. Annunziata, M. Capozzi, C. Cardellicchio, G. Fracchiolla, F. Naso, P. Tortorella, J. Am. Chem. Soc. 121 (1999) 4708.

[7] A. Gamma, L.Z. Flores-López, G. Aguirre, M. Parra-Hake, L.H. Hellberg, R. Somanathan, Arkivoc (2003) 4.

[8] I. Fernández, N. Khiar, Chem. Rev. 103 (2003) 3651.

[9] J.B. Jones, Tetrahedron 42 (1986) 3351.

[10] H.L. Holland, Chem. Rev. 88 (1988) 473.
[11] H.L. Holland, Organic Synthesis with Oxidative Enzymes, VCH, New York, 1992, p. 255.

[12] E.G. Mata, Phosphorus Sulfur Silicon Relat. Elem. 117 (1996) 231.

[13] H.L. Holland, Nat. Prod. Rep. 18 (2001) 171.

[14] H.L. Holland, F.M. Brown, G. Laksmaiah, B.G. Larsen, M. Patel, Tetrahedron: Asymmetry 8 (1997) 683.

[15] H.L. Holland, F.M. Brown, B.G. Larsen, Tetrahedron: Asymmetry 5 (1994) 1129.

[16] M. Madesclaire, A. Fauve, J. Metin, A. Carpy, Tetrahedron: Asymmetry 1 (1990) 311.

[17] H.L. Holland, C.G. Rand, P. Viski, F.M. Brown, Can. J. Chem. 69 (1991) 1989.

[18] H.L. Holland, F.M. Brown, B.G. Larsen, Tetrahedron: Asymmetry 6 (1995) 1561.

[19] H.L. Holland, F.M. Brown, Tetrahedron: Asymmetry 9 (1998) 535.

[20] H.L. Holland, P.R. Andreana, F.M. Brown, Tetrahedron: Asymmetry 10 (1999) 2833.

[21] B.J. Auret, D.R. Boyd, H.B. Henbest, C.G. Watson, K. Balenovic, V. Polak, V. Johanides, S. Divjak, Phytochemistry 13 (1974) 65.

[22] J.R. Cashman, L.D. Olsen, D.R. Boyd, R.A.S. McMordie, R. Dunlop, H. Dalton, J. Am. Chem. Soc. 114 (1992) 8772.

[23] C. Bolm, J. Legros, Chem. Eur. J. 11 (2005) 1086.

[24] A. Khatib, E.G. Wilson, H.K. Kim, A.W.M. Lefeber, C. Erkelens, Y.H. Choi, R. Verpoorte, Anal. Chim. Acta 559 (2) (2006) 264.

[25] S. Sang, K. Lapsley, W.-S. Jeong, P.A. Lachance, C.-T. Ho, R.T. Rosen, J. Agric. Food Chem. 50 (8) (2002) 2459.

[26] R.P. Collins, A.F. Halim, J. Agric. Food Chem. 20 (2) (1972) 437. 